\title{
Application of Resident Administration Services in The City of Paringin Web-Based
}

\author{
Rini Audia ${ }^{1,2, *}$, Bambang Sugiantoro ${ }^{1}$ \\ ${ }^{1}$ Informatics Departement, Faculty of Science and Technology, UIN Sunan Kalijaga, Indonesia \\ ${ }^{2}$ Informatics Education Department, Universitas Negeri Yogyakarta, Yogyakarta, Indonesia \\ Email*: audiarini03@gmail.com
}

\begin{abstract}
Paringin District have an application that is still in manual form and not computerized, and searching for information is still lacking because there is on online system so it is easy for citizents to access. So it is slow in the process of adding, changing and deleting data, and seeking information, as well as other population data collection. The purpose of making an administrative service application at this eligible village office so that it can help provide alternative problem solving such as data collection the number of people who come, move, die and are born. It's easy to get correspondence if needed quickly, get complete information for residents, safe in data storage in the long run and the data is neatly arrange in the application. The method in this study by utilizing certain techniques is with field studies and literature studies. The result of this study are a set of administrative service application software in the Layap village office of Paringin subdistrict. The conclusion of this study is that in the application design provides a lot of convenience in the data processing process in the village office.
\end{abstract}

Keywords: Application, PhpMyAdmin, Sublime text3, Web.

\section{INTRODUCTION}

Administration is one of the services carried out in one of the Layap village offices, Paringin District. This administration aims to record the entire population and record all events as important aspects of development. Administrative service applications have an important role in village governance and development planning. Village government is the government that has the authority to regulate and manage the administration and interests of the local community. The village government also has the function of providing services to the community and responsible for information that will later be reported to a higher agency, namely the District. Some types of administrative services that can be carried out at the village level include entering population data and changing population data, making certificates such as Marriage Certificate, Domicile Certificate, Entertainment License Certificate, Business License Certificate, Not Married Certificate, Death Certificate, Certificate of Disability, Business Certificate, and Land Purchase Agreement, all of which can be reported to the agencies above it.

As for the problems that are found that service to the community is still slow due to the unavailability of population data, the unavailability of population data makes the process of service takes a long time, the difficulty of obtaining data or information about the population and the absence of a computerized system at the village office for processing population data. With the related research description, the results of implementation in this application can simplify, accelerate and facilitate population information and easily obtain information or news in the village in Paringin sub-district. To improve accurate and efficient data collection, it is needed an online-based application as a means of handling population data processing and providing fast information. Because at present, the data collection system conducted at the Layap village office still uses bookkeeping as the main storage medium and uses Microsoft office excel for the presentation of population data and the lack of news information. So difficult to monitor the development of the population every month and service to the community is not optimal. Information about population numbers is inaccurate and requires a long process in making population reports.

\section{MATERIALS AND METHOD}

In this research method, there are a number of sections that are carried out, along with an explanation of each:

a. Data collection

Data collection through direct observation at the Village Office of Layap Paringin District, was carried out with a view to knowing the methods, procedures and data processing so that they could clearly know all the problems related to the system that was running. Conduct question and answer directly with relevant parties who can provide the necessary information. 
b. System Analysis

Analysis of the system that is currently running at the Layap Village Office is already using a computer in the field of service, but the data is still processed manually using Microsoft Word and Microsoft Excel. So that the search for data will be more difficult because they have to open one by one the existing files and it will take a long time to search for them.

c. System design

System design methods are prepared based on the results of data processing obtained. System design is done by applying the methods obtained from observations and literature studies. In this method the results of the program that are made will be displayed in the form of a table and also the form of a certificate. The report results from the input and output that will be generated.

d. Programming

The design results are then implemented into the Sublime text3 programming language with the Windows 10 Pro operating system which includes the interface creation and coding stages.

e. Program Testing

Test and analyze the program, based on user input and the resulting output accuracy. Experiments to run the system that has been made whether in accordance with what is desired.

\section{RESULTS AND DISCUSSION}

\section{Analysis of the Current System}

The current system in Layap Village is still using Microsoft Excel and Microsoft Word to present population data. Because data processing is less computerized resulting in difficulty in making reports.

From the above analysis it can be seen that the existing weaknesses in the current system are as follows:

1. Processing of population data is still manually, it is possible that errors or data manipulation can occur.

2. Too long the report presentation due to data processing manually, so that the expected timeliness cannot be met or achieved.

3. Some of the data documentation, is still ineffective and if a data report was needed a few years ago, it is possible that the data has been damaged or obsolete.

\section{CONCLUSIONS}

As for processing applications and discussions put forward in an Administrative Service Application at the Village Office of Layap Paringin District, the following conclusions can be drawn:

1. With the design of this application, it can provide facilities for officers in inputting data, correspondence and reporting, so as to ensure the accuracy of data and double data does not occur.

2. This application is a daily work aid for officers to be more effective and efficient. Applications that have been designed based on the activities carried out every day.

3. Produce accurate population reports.

4. Improving the performance of officers in providing services to the community.

\section{ACKNOWLEDGMENT}

Authors say thankfull to all those who have supported and helped research as well as in writing. We say thanks to Mr. Sugiantoro, our supervisor who gave ideas and guidance.

\section{REFERENCES}

Faisal, T. 2013. Service Information System Population services in the urban area of krapyak semarang by using delpi.

Herlina, Elin. 2014. Design of Population Data Information System in WEB-based Kutabaru Kelurahan. STIMIK Raharja

Marimin. 2013. Analysis and Design of Population Information System in Pamriyan Village, Pituruh District, Purworejo Regency.

Norlaila Hayati. 2015. Deed Data Processing Information System at the Population and Civil Registry Office of Balangan Regency.

Rahmawati, Maulida. 2015. Service Information System in Sungai Andai Banjarmasin Village based on WEB.

Retnosari, Dwi. 2015. Population Administration Service Information System at the Mekar Sari Village Office in Binuang District.

Rusli,said. 2012. Population Science Regulations. Jakarta: LP3ES

Sutabri, Tata. 2004. Analysis of Information Systems. Andi: Yogyakarta

Sutarman. 2012. Introductory Book of Information Technology. Jakarta: Mighty Earth. 